\title{
UNDERPRICING OF PRIVATE EQUITY/VENTURE CAPITAL BACKED IPOs. DO THEY DIFFER FROM OTHER OFFERS?
}

In this paper we analyze the underpricing of Private Equity/Venture Capital backed IPOs on the Warsaw Stock Exchange between 2003 and 2011. Although the average initial return was positive (11.4\%), it was significantly smaller than for other IPOs (14.5\%). These results may support theories that $\mathrm{PE} / \mathrm{VC}$ funds reduce information asymmetry between IPO investors and pre-IPO owners of the company or certification role of the PE/VC funds. At the same time our data do not give any evidence for the grandstanding or spinning hypotheses. Medium and longterm abnormal returns (1-month, 3-month and 1-year) on average are negative. In general, the more time elapses from the offer day, the lower the return from the PE/VC backed IPO investment. This data suggests that $\mathrm{PE} / \mathrm{VC}$ funds do not perform any certification role.

Keywords: new equity offerings, IPOs, underpricing, private equity, venture capital

JEL Classification: G11, G12, G14, O16

DOI: $10.15611 /$ aoe.2016.1.11

\section{INTRODUCTION}

Initial public offering (IPO) is an important step in the life of a company. The main objectives of IPOs are: raising funds, getting a current market valuation of a company and increasing its recognition among clients and investors. The stock market provides an access to capital which can be used for investments, including the acquisitions of other entities, building up working capital or paying off the company's debts. For the current owners of the company (pre-IPO investors), the introduction of shares to trade in an organized market is a way of investment exit. In most of the offers, the current investors sell a part of their stake in the company and in parallel the company carries out a new share issue to raise extra funds. The stock market is a preferable way of divestment during bullish periods, when companies' valuations are high. When stock prices are high the number of IPOs is significantly larger than the number of offers carried during a bear market.

\footnotetext{
* Cracow University of Economics

${ }^{* *}$ Jan Dlugosz University
} 
IPOs experience, on average, positive initial returns which is called underpricing. In most of the research, underpricing refers to the difference between the closing price of shares on the first day of trading and the issue price. This phenomenon is observed on the majority (if not all equity) markets in the world.

In this paper we analyze the underpricing of private equity and venture capital backed IPOs (PE/VC backed IPOs) on the Warsaw Stock Exchange. The first goal of this study is to answer the question of whether offers in which one of the sellers (or the unique seller) is a PE/VC fund, experience positive initial returns and if these returns are higher or lower than in the case of the other IPOs. We compare the results obtained for the Polish market with the results of the other research covering the European and the US market. The second goal is to check the performance of investment in the $\mathrm{PE} / \mathrm{VC}$ backed IPOs in the medium and long-term and against a benchmark equity price index.

The main reason that motivated us to write this paper is the lack of research concerning PE/VC backed IPOs on the Warsaw Stock Exchange, despite the fact that this market is one of the most active IPO spots in Europe. We believe that this study will contribute to extending the knowledge on the PE/VC backed IPOs that is almost exclusively based on data coming from developed stock markets.

\section{BASIC CONCEPTS AND DEFINITIONS}

\section{Private equity and venture capital}

Private equity is a form of equity investment into companies that are not quoted on a stock exchange. The private equity market consists of several specialized segments, such as: buy-out capital, venture capital, mezzanine capital, specialized real estate funds, secondary market and distressed funds. Private equity is characterized by its active investment model, in which it seeks to deliver operational improvements in companies that it is engaged in. Private equity funds invest in companies that are in late stages of development, i.e. relatively large businesses. The investment period is medium term and generally oscillates around three years. Investing in large and established businesses is associated with lower risk in comparison with investing into small companies. Many of the private equity investments are buy-out deals including leveraged buy-outs and management buy-outs. Management buyouts are often associated with mature companies with a high potential to generate positive cash flows. In many cases these are 
private companies whose owners do not want to continue the business, large companies that spin-off part of their business or public companies that are delisted after the transaction.

Venture capital investments can be defined as equity investments in unlisted companies that are in the earliest stages of development (seed and start-up) that operate in innovative industries with a high growth potential which translates into a high expected rate of return. On the other hand, a high expected rate of return means high investment risk. This explains why venture capital funds are also called risk capital funds. What is more, in many cases venture capital funds back entrepreneurs who have just the germ of a business idea ${ }^{1}$. The investment horizon of venture capital investment is between three and seven years. What is important is that both types of funds not only support companies in the form of capital, but also offer advisory services to the companies that they co-own. Moreover, the funds help companies to promote their products in a market.

As we can see from both definitions, the term private equity is broader than the term venture capital. Nevertheless, in this paper we will use both terms interchangeably. Summarizing the above considerations on the nature of private equity funds, their key characteristics are:

- funding is based on capital ownership (shareholding, equity capital);

- investments are focused on relatively young, innovative, high-growth private companies;

- funds provide business consulting and operational support to companies that they co-own;

- the medium and long-term nature of the investment;

- providing funds for high-risk companies and expecting above average returns on their investments.

\section{Initial Public Offering}

By Initial Public Offering (IPO) we understand an offer in which shares of a company are sold to the general public for the first time. Through this process, a private company transforms into a public company. This definition encompasses either offers in which companies raise new capital or offers in which only existing shares are sold. Naturally, offers which mix both types are also considered as IPOs ${ }^{2}$.

\footnotetext{
${ }^{1}$ The private equity and venture capital definitions are quoted from the website of the European Private Equity and Venture Capital Association (EVCA) and can be found on: www.evca.org.

${ }^{2}$ Investing in IPO, Investors bulletin, US Securities and Exchange Commission., No. 133 (2/13), 2013.
} 


\section{IPO underpricing}

In the existing literature there is no single measure of underpricing. In most of the research, underpricing refers to the difference between the closing price of an equity on the first day of trading and the issue price, which is called initial return. The initial return is calculated as follows:

$$
I R_{i}=\frac{P_{i, t}-P_{i, 0}}{P_{i, 0}}
$$

where $I R_{i}$ is the gross initial return for security $i$ from the last day of the subscription period to the closing of the first day of trading, $P_{i, t}$ is the closing price of security $i$ at the first day of trading, $P_{i, 0}$ is the issue price of security $i$ at the time of subscription ${ }^{3}$.

Initial return gives us the first glimpse of the profitability of an IPO investment, but it is not an accurate measure of investment profitability in real market conditions. The first-day closing price represents what the investors are willing to pay for the firm's shares. If the offer price is lower than the first-day closing price, the IPO is said to be underpriced and money is left on the table for new investors; formula (2). Since the existing shareholders settle for a lower offer price/proceeds than what they could have obtained, the money left on the table represents the wealth transfer from existing shareholders to new shareholders and it is calculated as follows:

$$
\text { Money left on the table }=\left(P_{i, t}-P_{i, 0}\right) Q
$$

where $Q$ is the number of shares offered and the rest of the symbols are the same as in formula (1).

The money left on the table is on average about twice the amount of the direct cost of carrying out an IPO, and for many firms it can be equal to several years of operating profit. Although most IPOs are underpriced, the level of underpricing varies across IPOs with different issue characteristics, allocation mechanisms, underwriter reputation, and general condition of the financial markets. For example, the level of underpricing is generally smaller for larger IPOs, those underwritten by prestigious investment banks, firms with a longer operating history or more experienced insiders on the board, and those companies which intend to use the IPO proceeds to repay debt ${ }^{4}$.

\footnotetext{
${ }^{3}$ This approach is used (among others) by Al-Hassan et al. (2007).

${ }^{4}$ L. Booth, The cost of going public, Why IPOs are typically underpriced, QFinance The Ultimate Financial Resource.
} 
On the other hand, technology firms, companies backed by venture capital, firms with negative earnings prior to the IPOs, or entities that went public during a bull market, experience greater underpricing ${ }^{5}$.

\section{Aftermarket Abnormal Return (AAR)}

Bearing in mind that an investor can choose between investment in shares offered in an IPO or choose other equities (alternative investment goals), we have to adjust formula (1). We believe that instead of buying IPO shares an investor can buy a market index. In the case of the Warsaw Stock Exchange, this will be the broad market index - WIG. We adjust (1) as follows:

$$
A A R_{i, t}=\frac{P_{i, t}-P_{i, 1}}{P_{i, 1}}-\frac{W I G_{i, t}-W I G_{i, 1}}{W I G_{i, 1}}
$$

where the second part of the equation is return on the WIG index in the analyzed period. We will check the performance of the investment in PE/VC backed IPOs 1, 3 and 12 months after the first day of trading. The rest of the symbols are the same as in (1).

\section{$P E / V C$ backed IPO}

Based on the previous definitions of the private equity and venture capital funds and IPO, we understand a PE/VC backed IPO as an initial offer in which one of the sellers is a private equity or venture capital fund, no matter how many shares it sells. IPOs make the venture capital industry tick since they provide them with the opportunities to exit their investment and at the same time realize positive returns ${ }^{6}$.

\section{RELATED LITERATURE}

\subsection{Theories that explain IPO underpricing}

In literature one may find many theories attempting to explain IPO underpricing. They may be grouped into four broad categories ${ }^{7}$ : asymmetric information, institutional, ownership and control and behavioural.

\footnotetext{
${ }^{5}$ N. Bhattacharaya, E. Demers, P. Joos, The relevance of accounting information in stock market bubble: evidence in internet IPO, Journal of Business Finance and Accounting, 37(3) pp. 291-321, April/May 2010.

${ }^{6}$ P. Gompers, J. Lerner, The Venture Capital cycle, The MIT Press, 1999.

${ }^{7}$ Ljungqvist (2006).
} 
Asymmetric information models assume that among the parties involved in a deal, i.e. the issuing firm, the broker advising on the deal and the new investors, one or two of them know more than the others. Consequently, this results in information frictions that cause underpricing. Institutional theories focus on the features of the market: possible litigation issues, the price stabilizing activities of brokers once trading starts, and taxes. Ownership and control theories claim that underpricing helps shape the shareholder base so as to reduce intervention by outside shareholders once the company goes public. Behavioural theories can be divided in two groups. The first one assumes the presence of "irrational" investors who bid up the price of IPO shares beyond the true value. The second one claims that a company that carries the IPO does not put enough pressure on the advising broker to set the issue price relatively higher. The broker wants to maximize the success of the IPO and low issue price raises the probability of the success. We focus on the theories of asymmetric information and ownership and control. Based on the literature we assume that these theories are the most suitable to explain the PE/VC IPO underpricing in the Polish market.

\section{Information asymmetry theories}

The term information asymmetry refers to the difference in information available to various investors in the market. Some investors may have more additional information about the market than others. This information can be generated through different channels like a strong analytical team or insider information. An increase in this asymmetry leads to the issue of rational decision making by informed investors and less rational of those uninformed whose number in the market (in the majority of cases) is larger. Uninformed investors, based on the information available to them, may make rational investment decisions which in some cases may lead to negative returns. Leland and Pyle (1977) were the first ones to suggest that information asymmetry can be reduced by financial intermediaries. Chemmanur and Fulghieri (1994) also supported the view that more information produced by investment bankers resulted in a decrease in information asymmetry. Rock (1986) showed that the underwriter may be more informed than individual investors but all investors in the market combined are more informed than $\mathrm{him} / \mathrm{her}$. The underwriter has expertise along with better information about the IPO market (as a whole), and the issuer and some investors may have access to private information (e.g. about competitors) that may affect the firm's value in the future. Sanders (1990) claims that underpricing is a competitive outcome which results from a small number of informed 
investors and a large number of uninformed ones. Academic literature paid a great deal of attention to this problem which is called "winner's curse". Some investors are viewed as informed while a larger group is viewed as uninformed. As a result, underpricing is directly related to the degree of information imperfection - or more specially information asymmetry - in the capital market and the cost of collecting information. Chemmanur (1993) claimed that underpricing is positively related to the increase in the number of investors that participate in the IPO and the cost of information production, while negatively related to the probability of there being a high value firm and the gross proceeds from the IPO. Chemmanur, Simonyan, Tehranian (2012) stated that venture capital team quality management play a certifying role in conveying a firm's intrinsic value to the market, reducing the information asymmetry. They assume that $\mathrm{PE} / \mathrm{VC}$-backed firms are associated with higher management quality compared to non-PE/VC backed firms. Second, both management quality and $\mathrm{PE} / \mathrm{VC}-$ backing have a positive effect on a firm's IPO underwriter reputation, offer size and post IPO analyst coverage, as well as on firm's valuation, both in the IPO and in the secondary market.

Underpricing may be due to the reputation of the underwriter among the investors. A reputable underwriter involved in an IPO process may have a positive impact on the value of the issue, resulting in underpricing. Chemmanur and Fulghieri (1994) suggested that the issuer has more information about the future prospects of the firm compared to the investment banker advising on the IPO process. Hence an important role of the investment banker is to produce and disseminate information about the issuing firm which will decrease the information asymmetry between the issuer and investors.

One of the most widely known theories that try to explain the underpricing of PE/VC-backed IPOs and which is based on information asymmetry is the grandstanding theory and venture capital certification hypothesis. It states that young venture capital firms quickly make private firms public in order to secure future funding from investors. Through successful IPOs they attempt to build their reputation among investors. However, rushing private firms in going public increases the level of underpricing as younger firms are less established and therefore more risky than their older counterparts. Riskier companies that conduct IPOs are more underpriced as documented by Ritter (1984). Underpricing is a form of compensation given to investors who undertake a greater risk. Tinic (1988) found that underwriters deliberately underprice IPOs due to the risk of their 
reputation loss; this allows investors to realize positive returns on IPO investments.

The venture capital certification hypothesis was formulated by Meggision and Weiss (1991), and stipulates that PE/VC funds act as certifying agents to the issuing firms. As these funds frequently bring companies to the market they put their credibility at stake. Moreover, they argue that $\mathrm{PE} / \mathrm{VC}$-backed companies attract prestigious underwriters, which should allow funds to sell their stake at higher prices and therefore reduce underpricing. This view was confirmed by Carter and Manaster (1991). The importance of the certification role is also underlined by Chahine (2006), who claims that on average PE/VC-backed IPOs in the UK are less underpriced than non-PE/VC-backed IPOs. Lin and Smith (1995) and Neus and Waltz (2004) assert that venture capitalists are perceived as insiders and a substantial sale of shares in IPOs would therefore be perceived by the market as a negative signal. Since PE/VC funds have a limited life span and require rates of return up to $50 \%$ (Sahlaman 1990), a high share overhang, which is the ratio of the shares retained by the PE/VC fund to the shares issued, can be associated with high underpricing.

\section{Ownership and control theories}

One of the best known ownership and control theories is the spinning hypothesis. It claims that the issuer firm's executives and venture capital investors hire underwriters that in future will offer them some side payments. IPO underpricing is a form of remuneration of the underwriters for the aforementioned payments. Spinning implies agreement between IPO decision-makers and the underwriter. Underwriters may find it convenient to underprice shares, principally to provide their clients with greater initial returns, which increases their reputation and renders their services much more marketable. According to Liu and Ritter (2010), through spinning underwriters allocate hot IPO shares (i.e. shares of other companies that conduct IPOs and that are perceived to be highly underpriced) to company executives in order to influence their decisions in the hiring of investment bankers and the pricing of their own company's IPO. PE/VC fund managers accept the underpricing of companies which they have in their portfolio because they obtain information on other hot and underpriced IPOs. This allows them to realize a positive return on their own capital which is accompanied with a relatively small investment risk. Furthermore, underwriters guarantee $\mathrm{PE} / \mathrm{VC}$ firms their support in the future and allow them to bring companies more easily to the public market. Coakley (2009) 
conducted research on venture capital backed IPOs in the UK in the period 1985-2003 and found empirical evidence of spinning, but only during the dotcom bubble.

\subsection{Underpricing of PE/VC backed IPOs}

Research on the underpricing of PE/VC backed IPOs can be grouped into two broad categories. The first one includes articles that claim that PE/VC backed IPOs are less underpriced than other IPOs (lower initial returns) and the second one claims that PE/VC backed IPOs are more underpriced than other IPOs (higher initial returns).

\section{Publications that claim the lower underpricing of PE/VC backed IPOS}

The lower underpricing of PE/VC backed IPOs can be attributed to the reduction of information asymmetry between private companies and their IPO investors. Therefore when a PE/VC fund controls an equity stake in such a firm, the underpricing of its IPO should be lower in comparison with other IPOs. Early work in this area support that notion. Barry, Muscarella, Peavy, and Vetsuypens (1990), in their pioneering paper on the US market, suggest that $\mathrm{PE} / \mathrm{VC}$ funds monitor private companies in which they have an equity stake and reduce asymmetric information between investors and managers of private firms. Superior monitoring leads to a reduction of underpricing, in fact it is significantly lower for venture capital backed IPOs than for other IPOs. IPOs of companies that are backed by "high quality" $\mathrm{PE} / \mathrm{VC}$ funds are less underpriced than IPOs of firms backed by "low quality" $\mathrm{VC}$ funds and argue that this is due to the monitoring and certification roles of "high quality" $\mathrm{PE} / \mathrm{VC}$ funds. High quality funds are those with a long operational history and their managers have well established returns of their portfolio. In a similar vein, Megginson and Weiss (1991) suggest that PE/VC firms "certify" the value of private firms and reduce the IPO underpricing of these firms. PE/VC funds achieve this by holding large equity stakes in private companies and remaining on the board of directors after the IPO. Lin and Smith (1995) proved that IPOs backed by $\mathrm{PE} / \mathrm{VC}$ firms with a well established reputation experience less underpricing when selling the majority of their shares. They assert that venture capitalists are perceived as insiders, and the strong sale of stocks at the IPO time would be seen as a negative signal by the market. In fact, since PE/VC funds generally hold part of their stake after the IPO as well, selling the majority or the whole stake would conduce outsiders to consider the new share issue as 
overpriced. Their empirical analyses confirm that PE/VCs are aware that holding their stake after the IPO is proof to underwriters and to the market that they are not acting opportunistically. Neus and Walz (2004) demonstrate that venture capital funds face a trade-off between the fund's reputation (which is a key determinant to obtaining future financing) and postponing the exit time (which leads to losing investment opportunities by the fund).

\section{Publications that claim the higher underpricing of PE/VC backed IPOs}

The second group of theories concerning the underpricing of $\mathrm{PE} / \mathrm{VC}-$ backed IPOs claims that the presence of the PE/VC fund among the shareholders of a company that carries out an IPO increases the level of underpricing. The main explanation of the higher underpricing for $\mathrm{PE} / \mathrm{VC}-$ backed IPOs is attributed to the aforementioned grandstanding theory (Gompers 1996) and the spinning hypothesis (Lougran and Ritter 2004). Gompers states that underpricing is a natural consequence of the greater risk perceived by the market when the venture capital fund takes young companies public, since these are still very risky due to their lifecycle phase. As was already mentioned, the spinning hypothesis states that the decision makers (managers of the PE/VC fund) in an IPO will strike a deal with underwriters to deliberately underprice the offer in order to receive an allocation of shares during hot IPO periods in the future.

Bradley and Jordan (2002) provided data that PE/VC-backed IPOs are more underpriced than non PE/VC-backed IPOs. Their study finds no evidence on the PE/VC certification role. Gompers (2005) states that since $\mathrm{PE} / \mathrm{VC}$ funds conduct a high number of IPOs during hot issue periods, it can be assumed that PE/VC-backed IPOs are more underpriced. Besseler and Seim (2011) conducted research on the underpricing of PE/VC-backed IPOs in Europe. They found that the level of underpricing, especially for venture capital backed IPOs, is higher during hot issue periods, such as the dot-com bubble and the pre-financial crisis period, than in other periods. These authors also found that underpricing in the period of 1998-2000 was much higher than during 2003-2007. Lee and Wahl (2004) point out that reputation is a key factor for venture capital firms because their funding is strictly correlated to the past performance of their investments, which is often measured by the number of investment exits via IPOs ${ }^{8}$. The finite lifetime of venture capital partnerships leads to frequent recapitalization,

\footnotetext{
${ }^{8}$ IPO is the preferable way of investment exit for private equity funds as it offers the highest return on investment.
} 
since venture capitalists have to cease operation when they cannot raise funds. In order to obtain funding, $\mathrm{PE} / \mathrm{VC}$ firms need a strong reputation which is built up by quick and excellent investment results (high return on invested capital). Hence, Gompers (1996) states that PE/VC funds, especially young ones, take companies to the market after a relatively short investment period, affirming that young $\mathrm{PE} / \mathrm{VC}$ funds usually grandstand because they are anxious to build a solid reputation, which will grant them access to new funds. Although grandstanding is common in PE/VC-backed IPOs, it has been proved that young PE/VC firms grandstand more than their older counterparts (e.g. private equity funds). Bringing companies to the stock market by $\mathrm{PE} / \mathrm{VC}$ firms is a clear signal for their potential future investors that the fund management has expertise and skills to aggressively manage the fund's portfolio with the aim of obtaining high returns. This observation is supported by data presented by Ritter ${ }^{9}$. According to him, the median age of US companies that carried out IPOs between 2002 and 2012 was 10 years. His data also show that the average age of PE/VC-backed companies that carried out IPOs in the US market for the period of 20022011 was 6.7 years.

\subsection{IPO underpricing - empirical data}

Most empirical studies demonstrate positive short-term returns for IPOs investments. In contrast, mixed results are found with respect to the longterm performance of IPOs. Although some studies provide evidence of positive market adjusted long-term IPO returns, insignificant or negative long-term returns are found in most research papers.

The short-term performance of IPOs significantly varies across markets. Ecbo (2005) presents statistics on the average initial IPO returns in 19902003 for 19 European countries and for 16 countries in Latin America and the Asia-Pacific region. In Europe the highest average initial IPO returns were in Poland (over 60\%) followed by Greece, Germany and Ireland (around 40\%). In contrast, the lowest average initial returns were in Luxembourg (ca. 5\%) and Denmark (less than 10\%). In other regions the highest average initial IPO returns were in Malaysia (around 90\%) followed by Thailand and Singapore (over 30\%). The lowest average initial returns were in Latin American countries including Chile, Uruguay, Mexico and Brazil (less than 5\%). An important conclusion that can be drawn from this data is that although the average initial returns vary significantly across

\footnotetext{
${ }^{9} \mathrm{http}: / /$ bear.warrington.ufl.edu/ritter/ipodata.htm
} 
markets, they are always positive. This observation is supported by other studies.

Al-Hassan et al (2007) analyzed 47 IPOs in six markets in the Gulf region that went public between 2001 and 2006. They show that the average initial return for these IPOs equalled $290 \%$, which is one of the highest returns that can be found in the existing literature ${ }^{10}$. Moreover, they demonstrate that although in a one-year horizon IPO returns beat the market benchmark, they turn negative once the initial returns are excluded, which is consistent with findings in other markets.

Aggraval et al (2004) examined the relation between investor demand for shares offered in IPOs prior to the offerings and the aftermarket performance of IPOs from 1993 to 1997 on the Hong Kong stock market. They found that IPOs with high investor demand have large positive initial returns but negative long-term excess returns. Consequently, IPOs with low investor demand have negative initial returns but positive long-term excess returns.

Aussenegg (2000) analyzes the performance of initial public offerings on the Polish stock market between 1991 and 1999 for two sets of companies: the private and public sector. He demonstrates that these IPOs were significantly underpriced, as the average initial return equalled $38.5 \%$. Moreover, the IPOs of public sector companies yielded significantly higher returns than the private ones (65.6\% and $25.3 \%$ on average respectively). Also the market adjusted average initial return was positive and equalled $33.1 \%$ for the whole sample of companies. The long-term performance of the private and public sector companies was not significantly different from each other. During the first three years of aftermarket trading they neither under- nor over-performed benchmarks.

Lyn and Zychowicz (2002) analyzed the performance of 103 IPOs carried in Polish and Hungarian markets between 1991 and 1998. They found that the first-day market-adjusted average return in Poland equalled $15.1 \%$ while in Hungary it was $54.4 \%$. The authors suggest that one of the possible explanations for this disproportion is the different investors' structure in both markets. In Hungary in 1996, foreign investors controlled approximately $85 \%$ of the market's free float while in Poland only $30 \%$. They claim that the foreign investors probably possess the experience, expertise and resources that could reduce informational asymmetries, which should correspond to less underpricing. However, this explanation rather suggests that

\footnotetext{
${ }^{10}$ Another example of extremely high IPO average initial returns (also 290\%) is presented in the study by Mok and Hui for the Chinese market.
} 
underpricing in Hungary should be lower than in Poland, taking into account the almost three times higher participation of foreign investors in the Hungarian market in comparison with the Polish one. Medium (1M, 3M and $6 \mathrm{M})$ and long-run (1Y, $2 \mathrm{Y}$ and $3 \mathrm{Y}$ ) abnormal returns (i.e. after correction for changes of BUX and WIG indices respectively) in both markets in most of the cases were strongly negative or close to $0 \%$. The authors found that the primary determinant of initial returns in these markets was market momentum, i.e. the percentage change in the local market index one month prior to the offering day. An interesting finding is that the size of the offer was not found to be significantly related to initial returns. This is in contrast with asymmetric information theories which claim that the larger the offer the lower the information asymmetry, thus the lower the level of underpricing. In contrast to Aussenegg, they do not find any significant difference between the underpricing of privatization and non-privatization IPOs.

Sukacz (2005) studied 185 IPOs carried in the Polish market between 1991 and 2002. He founds that the average underpricing during the first-day of listing equalled $26 \%$. IPOs' underpricing was positively related to the number of days and the change of the broad market index WIG between the last day of the subscription period to the first day of listing, and it was negatively related to such financial ratios as $\mathrm{P} / \mathrm{E}$ and $\mathrm{P} / \mathrm{BV}$. In contrast to Aussenegg (2000), he claims that the average initial return on IPOs of private companies was higher than on IPOs of privatized firms and equalled $27.4 \%$ and $25.5 \%$ respectively. Moreover, he found that the initial return on IPOs of smaller companies (i.e. listed in the WSE parallel market) was higher than of larger firms (i.e. listed on the WSE main market).

The latest research concerning the Polish market was done by Sieradzki $(2013)^{11}$. He analyzed 314 IPOs on the Warsaw Stock Exchange between 2003 and 2011. The average initial return equalled 14.2\%. Not surprisingly the highest initial returns were yielded by IPOs of private domestic companies and (what is more striking) offers made by companies that migrated to the WSE from other markets, i.e. the RPW CeTO market or NewConnect platform. Those markets where smaller companies are listed are alternative markets to the WSE. This observation goes against the information asymmetry theories of IPOs underpricing. Also the abnormal initial return was the highest in case of the latter companies. The same

\footnotetext{
${ }^{11}$ Sieradzki, R., Does it Pay to Invest in IPOs? Evidence from the Warsaw Stock Exchange, National Bank of Poland Working Paper No. 139 January 2013, Warsaw.
} 
outcome of Polish IPO market was given by Jewartowski and Lizińska (2012). Their paper documents the short and long-term performance of initial public offerings on the WSE from 2000 to 2008. The study reveals positive initial market-adjusted returns of $13.95 \%$ and significant long-term underperformance with a mean of $-22.62 \%$ for the three-year buy-and-hold strategy.

A summary of research concerning IPO underpricing is presented in Table 1.

Table 1

Equally weighted average IPO initial returns in selected countries

\begin{tabular}{|c|c|c|c|c|}
\hline Country & Source & $\begin{array}{l}\text { Number } \\
\text { of IPOs }\end{array}$ & Period & Return \\
\hline Australia & Lee, Taylor and Walter; Woo; Pham; Ritter & 1,103 & 1976-2006 & $19.8 \%$ \\
\hline Austria & Aussenegg & 96 & $1971-2006$ & $6.5 \%$ \\
\hline Belgium & $\begin{array}{l}\text { Rogiers, Manigart and Ooghe; Manigart; } \\
\text { DuMortier; Ritter }\end{array}$ & 114 & 1984-2006 & $13.5 \%$ \\
\hline Brazil & Aggarwal, Leal and Hernandez; Saito & 180 & $1979-2006$ & $48.7 \%$ \\
\hline Canada & $\begin{array}{l}\text { Jog and Riding; Jog and Srivastava; } \\
\text { Kryzanowski, Lazrak and Rakita; Ritter }\end{array}$ & 635 & 1971-2006 & $7.1 \%$ \\
\hline China & Chen, Choi and Jiang (A Shares) & 1,394 & $1990-2005$ & $164.5 \%$ \\
\hline Denmark & Jakobsen and Sorensen; Ritter & 145 & 1984-2006 & $8.1 \%$ \\
\hline Finland & Keloharju & 162 & 1971-2006 & $17.2 \%$ \\
\hline France & $\begin{array}{l}\text { Husson and Jacquillat; Leleux and } \\
\text { Muzyka; Paliard and Belletante; Derrien } \\
\text { and Womack; Chahine; Ritter }\end{array}$ & 686 & 1983-2006 & $10.7 \%$ \\
\hline Germany & Ljungqvist; Rocholl; Ritter & 652 & $1978-2006$ & $26.9 \%$ \\
\hline Greece & Nounis, Kazantzis and Thomas & 363 & $1976-2005$ & $25.1 \%$ \\
\hline Hong Kong & $\begin{array}{l}\text { McGuinness; Zhao and Wu; Ljungqvist } \\
\text { and Yu; Fung, Gul and Radhakrishnan; } \\
\text { Ritter }\end{array}$ & 1008 & 1980-2006 & $15.9 \%$ \\
\hline India & Marisetty and Subrahmanyam & 2,811 & 1990-2007 & $92.7 \%$ \\
\hline Indonesia & $\begin{array}{l}\text { Hanafi; Ljungqvist and Yu; Danny; } \\
\text { Suherman }\end{array}$ & 321 & 1989-2007 & $21.1 \%$ \\
\hline Ireland & Ritter & 31 & 1999-2006 & $23.7 \%$ \\
\hline Israel & $\begin{array}{l}\text { Kandel, Sarig and Wohl; Amihud and } \\
\text { Hauser; Ritter }\end{array}$ & 348 & 1990-2006 & $13.8 \%$ \\
\hline Italy & $\begin{array}{l}\text { Arosio, Giudici and Paleari; Cassia, Paleari } \\
\text { and Redondi; Vismara }\end{array}$ & 233 & $1985-2006$ & $18.2 \%$ \\
\hline Japan & $\begin{array}{l}\text { Fukuda; Dawson and Hiraki; Hebner and } \\
\text { Hiraki; Pettway and Kaneko; Hamao, } \\
\text { Packer, and Ritter; Kaneko and Pettway; } \\
\text { Ritter; TokyoIPO.com }\end{array}$ & 2579 & $1970-2007$ & $40.5 \%$ \\
\hline Korea & $\begin{array}{l}\text { Dhatt, Kim and Lim; Ihm; Choi and Heo; } \\
\text { Ng; Cho; Ritter }\end{array}$ & 1417 & 1980-2007 & $57.4 \%$ \\
\hline Malaysia & Isa; Isa and Yong; Yong & 350 & $1980-2006$ & $69.6 \%$ \\
\hline
\end{tabular}


Table 1, cont.

\begin{tabular}{l|l|c|c|c}
\hline Mexico & $\begin{array}{l}\text { Aggarwal, Leal and Hernandez; } \\
\text { Eijgenhuijsen and van der Valk }\end{array}$ & 88 & $1987-1994$ & $15.9 \%$ \\
\hline $\begin{array}{l}\text { The } \\
\text { Netherlands }\end{array}$ & $\begin{array}{l}\text { Wessels; Eijgenhuijsen and Buijs; } \\
\text { Jenkinson, Ljungqvist and Wilhelm; Ritter }\end{array}$ & 181 & $1982-2006$ & $10.2 \%$ \\
\hline New Zealand & Vos and Cheung; Camp and Munro; Ritter & 214 & $1979-2006$ & $20.3 \%$ \\
\hline Norway & $\begin{array}{l}\text { Emilsen, Pedersen and Saettem; Liden; } \\
\text { Ritter }\end{array}$ & 153 & $1984-2006$ & $9.6 \%$ \\
\hline Poland & Jelic and Briston; Ritter & 224 & $1991-2006$ & $22.9 \%$ \\
\hline Portugal & Almeida and Duque; Ritter & 28 & $1992-2006$ & $11.6 \%$ \\
\hline Russia & Ritter & 441 & $1999-2006$ & $4.2 \%$ \\
\hline Singapore & Lee, Taylor and Walter; Dawson; Ritter & 128 & $1986-2006$ & $28.3 \%$ \\
\hline Spain & Ansotegui and Fabregat; Alvarez Otera & $40.9 \%$ \\
\hline Sweden & Rydqvist; Schuster; Simonov; Ritter & $1980-2006$ & $27.3 \%$ \\
\hline Switzerland & $\begin{array}{l}\text { Kunz, Drobetz, Kammermann and } \\
\text { Walchli; Ritter }\end{array}$ & 147 & $1983-2006$ & $29.3 \%$ \\
\hline Taiwan & Chen & 1,312 & $1980-2006$ & $37.2 \%$ \\
\hline $\begin{array}{l}\text { Thailand } \\
\text { and Tirapat; Ekkayokkaya and Pengniti }\end{array}$ & 459 & $1987-2007$ & $36.6 \%$ \\
\hline Turkey & Kiymaz; Durukan; Ince & 282 & $1990-2004$ & $10.8 \%$ \\
\hline $\begin{array}{l}\text { The United } \\
\text { Kingdom }\end{array}$ & Dimson; Levis & 12,007 & $1960-2007$ & $16.9 \%$ \\
\hline $\begin{array}{l}\text { The United } \\
\text { States }\end{array}$ & Ibbotson, Sindelar and Ritter; Ritter & $1959-2006$ & $16.8 \%$ \\
\hline
\end{tabular}

Source: based on J. Ritter IPO data base https://site.warrington.ufl.edu/ritter/ipo-data/

\subsection{Underpricing of PE/VC backed IPOs in selected countries}

The United States have one of the best developed stock markets in the world, which offers $\mathrm{PE} / \mathrm{VC}$ funds ample opportunities to exit their investments via IPOs. It is not a coincidence that the number of risk capital backed IPOs is the highest in the world. The average initial returns between 1980 and 2010 equalled $18.0 \%$. The IPO underpricing of the VC-backed offers was over two times higher than the underpricing of other IPOs (Table 2 ). These statistics were highly influenced by the returns on IPOs of risk capital backed companies that operated in the internet sector. As we can see from Table 3, the underpricing of the VC-backed IPOs in 1999-2000 was exceptionally high and equalled $82.5 \%$, while for other companies it was $38.4 \%$. It is not a coincidence that in the long run the share prices of $\mathrm{VC}-$ backed companies significantly underperformed in the market. In the latter period the difference in IPO underpricing between $\mathrm{VC}$-backed and other companies was much smaller. Although, in the long run shares of the VCbacked companies underperformed in the market, it was not as pronounced as in the case of the internet bubble period IPOs. 
Table 2

Long-term performance of US VC-backed and non VC-backed IPOs, 1980-2010

\begin{tabular}{l|c|c|c|c}
\hline \multicolumn{1}{c|}{ 1980-2010 } & Number of IPOs & $\begin{array}{c}\text { Average } \\
\text { underpricing }\end{array}$ & $\begin{array}{c}\text { 3 year } \\
\text { BHR }\end{array}$ & $\begin{array}{c}\text { 3 year } \\
\text { BHAR }\end{array}$ \\
\hline VC-backed & 2,634 & 27.9 & 23.2 & -12.5 \\
\hline Non VC-backed & 4,897 & 12.6 & 19.5 & -23.6 \\
\hline All & 7,531 & 18.0 & 20.8 & -19.7 \\
\hline
\end{tabular}

Source: based on J. Ritter IPO data base https://site.warrington.ufl.edu/ritter/ipo-data/

Table 3

Long-term performance of US VC-backed and non VC-backed IPOs, 1999-2000 and 2001-2010

\begin{tabular}{l|c|c|c|c}
\hline \multicolumn{1}{c|}{ 1999-2000 } & $\begin{array}{c}\text { Number } \\
\text { of IPO }\end{array}$ & $\begin{array}{c}\text { Average } \\
\text { underpricing }\end{array}$ & 3 year BHR & 3 year BHAR \\
\hline VC-backed & 507 & 82.5 & -63.4 & -41.5 \\
\hline Non VC-backed & 349 & 38.4 & -38.6 & -17.9 \\
\hline All & 856 & 64.5 & -53.3 & -31.9 \\
\hline $2001-2010$ & Number of IPO & Average underpricing & 3 year BHR & 3 year BHAR \\
\hline VC-backed & 372 & 14.9 & 4.3 & -8.4 \\
\hline Non VC-backed & 640 & 9.7 & 18.2 & 8.0 \\
\hline ALL & 1012 & 11.6 & 13.1 & 2.0 \\
\hline
\end{tabular}

Source: based on J. Ritter IPO data base https://site.warrington.ufl.edu/ritter/ipo-data/

Bessler and Seim (2011), analysed European PE/VC-backed IPOs in 1996-2010. Their analysis covered two complete stock market cycles and two IPO waves. The authors analysed data in two sub-periods, i.e. 19962003 and 2003-2010, in order to find any difference in returns. Their findings provide evidence that $\mathrm{PE} / \mathrm{VC}-$ backed IPOs gave positive returns for a specific period subsequent to IPO. In fact, early stage investors that own company's shares prior to IPO, realized profit first from the initial return and second from the high positive returns during the first year after going public. The average initial return for the whole sample was $8.4 \%$ and the median equalled $0.7 \%$. IPO investments generate on average positive returns for investors for nearly three years after the IPO day. Moreover, the initial returns for large $\mathrm{PE} / \mathrm{VC}-$ backed IPOs, i.e. with market values over EUR100m, significantly outperform those of non PE/VC backed IPOs of the same value. 


\section{$P E / V C$ activity in the IPO market of the WSE}

Table 4 shows that funds used IPOs as a way of divestments not in a systematic manner. This is partly caused by the small size of the PE/VC market in Poland where large individual transactions have a significant impact on market statistics (e.g. in 2009). Nevertheless, IPOs were one of the most preferable ways of divestments for the funds because they offered them relatively high returns.

Table 4

Ways of investment exits by PE/VC funds in Poland (in \%), 2007-2011

\begin{tabular}{l|r|r|r|r|r}
\hline \multicolumn{1}{c|}{ Way of investment exit } & $\mathbf{2 0 0 7}$ & $\mathbf{2 0 0 8}$ & $\mathbf{2 0 0 9}$ & $\mathbf{2 0 1 0}$ & $\mathbf{2 0 1 1}$ \\
\hline Trade sales & 17.6 & 24.0 & 19.9 & 9.5 & 69.2 \\
\hline IPO & 3.5 & 0.4 & 45.4 & 0.8 & 20.3 \\
\hline Write-off & 0.0 & 3.0 & 0.0 & 47.0 & 0.0 \\
\hline Repayment of interest & 0.0 & 20.9 & 0.0 & 0.0 & 0.0 \\
\hline Repayment of loans & 14.0 & 0.0 & 0.0 & 0.0 & 0.2 \\
\hline Sale to another fund & 49.8 & 39.0 & 1.9 & 17.1 & 2.3 \\
\hline Sale to financial institution & 1.6 & 0.0 & 31.7 & 0.2 & 5.8 \\
\hline Buy-out & 2.4 & 5.2 & 0.0 & 25.4 & 2.0 \\
\hline Other & 11.2 & 7.4 & 1.1 & 0.0 & 0.2 \\
\hline
\end{tabular}

Note: data concerning 2003-2006 are not available.

Source: EVCA Yearbook 2012

Table 5

The share of PE/VC backed IPOs on the WSE, 2004-2011

\begin{tabular}{l|c|c|l|c|c|c}
\hline Year & $\begin{array}{c}\text { Number } \\
\text { of PE/VC } \\
\text { backed } \\
\text { IPOs }\end{array}$ & $\begin{array}{c}\text { Total } \\
\text { number } \\
\text { of IPOs }\end{array}$ & $\begin{array}{c}\text { Share } \\
\text { in \% }\end{array}$ & $\begin{array}{c}\text { Value } \\
\text { of PE/VC } \\
\text { backed } \\
\text { IPOs (in } \\
\text { PLN } \\
\text { trillion) }\end{array}$ & $\begin{array}{c}\text { Total } \\
\text { value } \\
\text { of IPOs } \\
\text { (in PLN } \\
\text { trillion) }\end{array}$ & $\begin{array}{c}\text { Share } \\
\text { in \% }\end{array}$ \\
\hline 2004 & 5 & 36 & 13.9 & 0.545 & 12.7 & 4.3 \\
\hline 2005 & 7 & 35 & 20 & 0.731 & 7.0 & 10.4 \\
\hline 2006 & 9 & 38 & 23.7 & 0.456 & 4.2 & 11.0 \\
\hline 2007 & 7 & 81 & 8.6 & 0.746 & 8.4 & 8.8 \\
\hline 2008 & 1 & 33 & 3.0 & 0.019 & 3.2 & 0.006 \\
\hline 2009 & 0 & 13 & 0 & 0.000 & 15.4 & 0 \\
\hline 2010 & 2 & 34 & 5.9 & 0.133 & 15.3 & 0.009 \\
\hline
\end{tabular}

Source: WSE and own calculations 
The share of PE/VC backed IPOs in the total number of IPOs on the Warsaw Stock Exchange in 2004-2011 was in the range 0-23.7\%. The share of the PE/VC funds in the IPO market based on the IPO value varied significantly across the years (Table 5). As was mentioned before, this was mainly due to the small size of the market. In such a market, one large transaction may have a dramatic impact on the PE/VC backed IPO value. Funds were the most active in the IPO market in 2004-2007. This is not surprising as in those years WSE experienced a period of rising equity prices and high demand for shares among investors.

\section{EMPIRICAL RESULTS}

Our analysis covers all IPOs on the Warsaw Stock Exchange between 2004 and 2011. The sample includes 314 offers, of which 33 were PE/VC backed. Most of the PE/VC backed offers (28 IPOs) were carried out between 2004-2007 when the WSE experienced a period of rising equity prices and high relative valuations of stocks.

The average value of IPOs carried by PE/VC backed companies was two and half times smaller than in case of other IPOs (Table 6). Such a big difference in average offer sizes was mainly influenced by the large offers of state-owned companies. The median IPO value shows that PE/VC backed IPOs were larger than average but the difference in median IPO value is not that significant as in the case of the average value. Nevertheless, PE/VC funds mainly introduced medium sized businesses to the market.

Table 6

Basic descriptive statistics of PE/VC backed IPOs on the WSE, 2004-2011

\begin{tabular}{l|c|c|c}
\hline & All IPOs & $\begin{array}{c}\text { PE/VC } \\
\text { backed IPOs }\end{array}$ & $\begin{array}{c}\text { Non PE/VC } \\
\text { backed IPOs }\end{array}$ \\
\hline Average IPO value (PLN million) & 241 & 92 & 258 \\
\hline Median IPO value (PLN million) & 36 & 53 & 35 \\
\hline
\end{tabular}

Source: own calculations

As can be seen from Table 7, the average initial return for PE/VC backed IPOs was $11.4 \%$ and $14.5 \%$ for non-PE/VC backed offers. This means that PE/VC backed IPOs were less underpriced than other IPOs in the Polish market. This result supports theories that claim that $\mathrm{PE} / \mathrm{VC}$ funds reduce 
information asymmetry between IPO investors and pre-IPO owners of the company or the certification role of the PE/VC funds. The reduction of the information asymmetry or the certification "effect" must be substantial bearing in mind that in general the level of underpricing is higher during a bull market and this is also the time when PE/VC funds carried most of the IPOs (Figure 1). In addition to that, some researchers claim that larger IPOs are associated with lower information asymmetry (Ljungqvist 2005). In Poland the average value of PE/VC backed offers was PLN 92 million in comparison with PLN 241 million for other IPOs.

At the same time our data do not give any evidence for grandstanding or spinning hypotheses. Underpricing of the venture capital backed IPOs on the WSE is lower than in the US market (14.9\%), although it should be underlined that the periods when underpricing was examined do not exactly match each other. What should be pointed out is that the underpricing of the venture capital backed IPOs in the US is significantly higher than the underpricing of other IPOs, which is exactly opposite to the pattern observed in the Polish market.

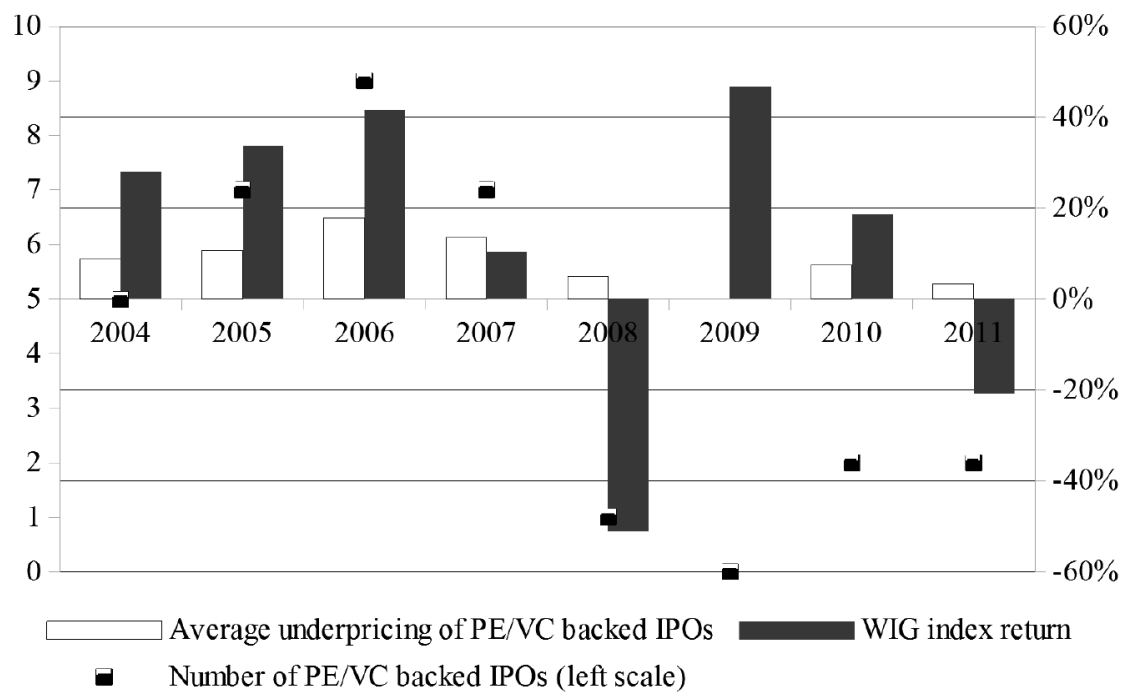

Figure 1. WIG index yearly returns and the number and initial return of PE/VC backed IPOs, 2004-2011

Source: own calculations 
Table 7

Basic descriptive statistics for IPO initial returns on the WSE, 2004-2011

\begin{tabular}{l|r|r|c}
\hline & All IPOs & $\begin{array}{c}\text { PE/VC backed } \\
\text { IPOs }\end{array}$ & $\begin{array}{c}\text { Non PE/VC } \\
\text { backed IPOs }\end{array}$ \\
\hline Average & 14.2 & 11.5 & 14.5 \\
\hline Median & 5.0 & 4.8 & 5.0 \\
\hline Standard deviation & 44.2 & 20.0 & 46.2 \\
\hline Skewness & 6.7 & 1.9 & 6.5 \\
\hline Kurtosis & 62.0 & 6.9 & 57.7 \\
\hline Min & -75.2 & -8.9 & -75.2 \\
\hline Max & 481.3 & 85 & 481.3 \\
\hline
\end{tabular}

Source: own calculations

Six offers (18.2\% of all PE/VC backed IPOs) yielded negative initial returns and in the case of the other $15 \mathrm{PE} / \mathrm{VC}$ backed IPOs $(45.5 \%$ of all $\mathrm{PE} / \mathrm{VC}$ backed IPOs), initial returns did not surpass $10 \%$. At the other extreme were two IPOs with initial returns exceeding 50\% and $80 \%$ (Figure 2). The standard deviation of initial returns in the case of PE/VC backed IPOs was over two times smaller than in the case of other IPOs. If we assume that standard deviation is an adequate measure of investment risk, this means that lower average initial returns were associated with lower risk. In fact the reduction of risk was much bigger than the reduction of average initial return. In comparison with non PE/VC backed IPOs, the percentage of IPOs with negative initial returns was lower. Non PE/VC IPOs yielded negative returns in $27.1 \%$ of cases, while with the PE/VC backed IPOs it was $18.2 \%$. This partly can be explained by a statistical effect which roots in a relatively low number of PE/VC backed IPOs. In their case the weight of one observation in the sample is slightly higher than $3 \%$ in contrast to less than $0.3 \%$ for the whole sample. A theoretical explanation may be that $\mathrm{PE} / \mathrm{VC}$ fund managers and managers of the firms offering shares in IPOs knew better the value of their companies than was the case of other corporates and appraised them more accurately. In fact, they know better the market that a company operates in, its competition, future cash flows, etc. than an advisory firm that introduces a company to the stock market, but before the transaction it does not have any contact with it. This would explain not only the lower number of IPOs with negative initial returns in comparison with other IPOs, but also the lower average initial return and its lower standard deviation. Nevertheless, to point out the factors that cause or contribute to the lower level of underpricing of $\mathrm{PE} / \mathrm{VC}$ backed companies in 
comparison with their counterparts requires further investigation based on case studies of the whole sample of PE/VC backed IPOs carried on the WSE.

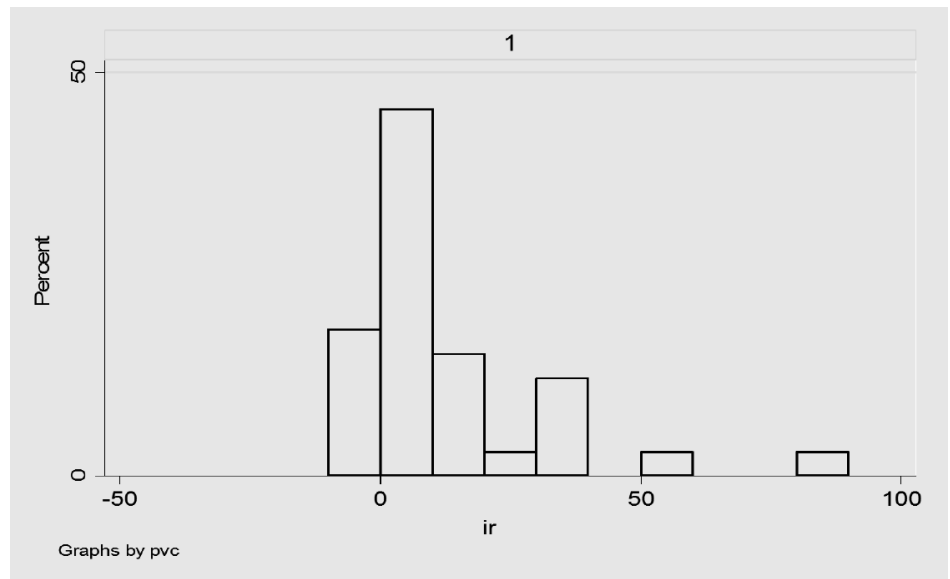

Figure 2. Distribution of initial returns of the PE/VC backed IPOs on the WSE, 2004-2011 Source: own calculations

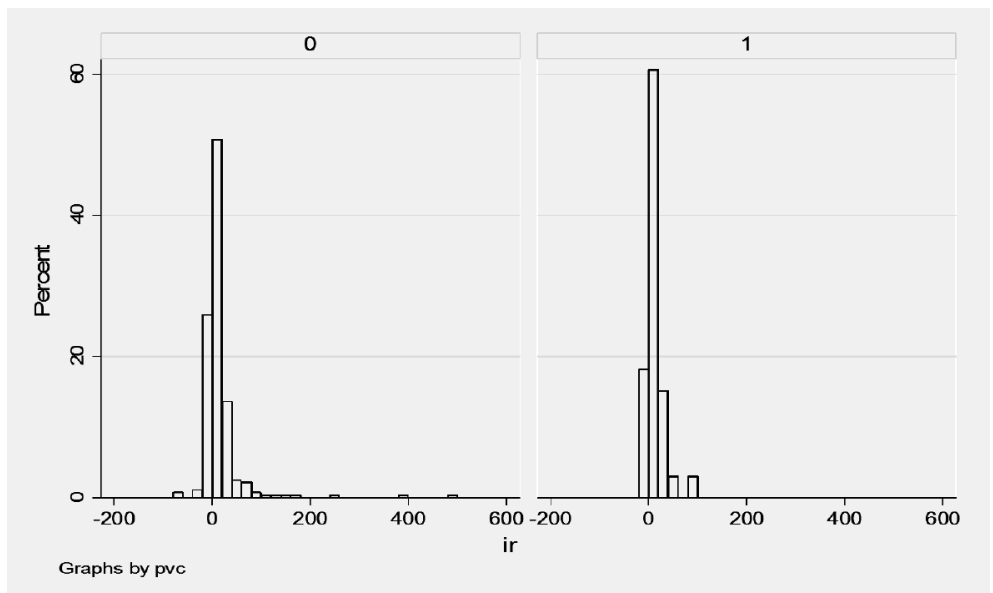

Note: "1" refers to PE/VC backed IPOs and " 0 " to the other offers.

Figure 3. IPO initial returns on the WSE: PE/VC backed vs. non PE/VC backed, 2004-2011

Source: own calculations 
The initial returns of venture capital backed IPOs are more concentrated around the mean than in the case of the normal distribution but at the same time they deviate more from the mean than the initial returns of other IPOs smaller kurtosis (Figure 3). For both types of IPOs the skewness is positive, which means that both distributions have long right tails, i.e. they include observations with large positive initial returns. The skewness is much larger in the case of non PE/VC backed IPOs which reflects several offers that yielded very large initial returns which surpassed $100 \%$.

Initial returns can be analyzed in connection with the performance of the stock market. As was said before, PE/VC funds carry out IPOs mainly during bullish periods in the stock market so the sample of IPOs that we analyze is biased. In years when equity valuations are low, funds prefer to divest their investments in other ways, i.e. selling companies to other funds or strategic investors. This also happened in Poland in the period 2004-2011. Funds were the most active in introducing companies to the WSE between 2004 and 2007 when the Polish stock market experienced sharp increases of equity prices (Figure 1), which was among other things, a consequence of the country's accession to the European Union and a bullish period in the world's leading equity markets. The highest average underpricing of $\mathrm{PE} / \mathrm{V}-$ backed IPOs was in 2006 when funds also carried a record high number of offers. The lowest average IPO underpricing was observed in 2008 and 2011 which can be attributed to the bearish stock market. In 2009, funds did not introduce any portfolio company to the WSE. In 2010, in spite of the relatively good situation in the stock market, the average initial return on IPO shares was also relatively low. One of the explanations is that in 2010 the volatility in most of the stock markets was high, reflecting the uncertainty of investors which made them reluctant to invest in equities. Moreover, we must bear in mind the very small number of IPOs in that year which does not allow us to draw definite conclusions.

\section{Aftermarket Abnormal Return}

As can be seen from the Table 8, PE/VC backed IPO returns turn negative in one month, three months and a one year period after adjusting for changes of the broad market index WIG. In general, the more time elapses from the IPO day, the lower the return. Holding shares one and three months after the IPO day results in -1.7 and $-3.4 \%$ average abnormal returns respectively. Holding shares one year after the IPO yielded on average a negative abnormal return of $6.8 \%$. Investments in other IPOs perform relatively better. This may suggest that $\mathrm{PE} / \mathrm{VC}$ funds sell shares during the 
initial offer at relatively high prices and do not care about the performance of the equity prices after the IPO. Investors at the time of the offer do not realize that they pay relatively too much for the shares offered by the companies backed by $\mathrm{PE} / \mathrm{VC}$ funds. It takes them some time to draw this conclusion.

Table 8

Aftermarket Abnormal Returns on the WSE: PE/VC backed vs non-PE/VC backed, 2004-2011

\begin{tabular}{l|c|c|c}
\hline & All IPOs & $\begin{array}{c}\text { PE/VC backed } \\
\text { IPOs }\end{array}$ & $\begin{array}{c}\text { Non PE/VC } \\
\text { backed IPOs }\end{array}$ \\
\hline AAR 1M & -1.73 & -1.71 & -1.75 \\
\hline AAR 3M & -1.0 & -3.35 & -0.78 \\
\hline AAR 1Y & -4.2 & -6.76 & -1.44 \\
\hline
\end{tabular}

Source: own calculations

\section{SUMMARY AND CONCLUDING REMARKS}

The first goal of this study was to answer the questions of whether offers in which one of the sellers is a $\mathrm{PE} / \mathrm{VC}$ fund experience positive initial returns, and if these returns are higher or lower than in the case of the other IPOs. The second goal was to check the performance of the investment in the PE/VC backed IPOs in the medium and long run and against a benchmark equity price index.

Based on our data we can draw a conclusion that although PE/VC backed IPOs yield on average positive returns, they are smaller than in the case of other IPOs. What is more, in the medium and long run the share prices of companies that were PE/VC backed at the time of the IPO perform worse than the broad market index. This may suggest that funds sell shares during IPOs at relatively high prices. Nevertheless, the long-term underperformance of $\mathrm{PE} / \mathrm{VC}$ backed IPO shares is more pronounced in comparison with the IPOs of other companies. Share underpricing of the $\mathrm{PE} / \mathrm{VC}$ backed companies sold on the WSE is smaller than in the US market. What is more, in the US the average initial return on $\mathrm{PE} / \mathrm{VC}$ backed companies is higher than in the case of other IPOs, which is exactly the opposite to what we observe in Poland. The comparison of the aftermarket abnormal returns obtained for the Polish and American market is difficult as the periods of the analysis are not the same. 
The future research on the subject may include a larger set of countries taken into consideration or a longer period of time. One of the natural areas would be the inclusion in the study of other IPO markets in the region of Central and Eastern Europe ${ }^{12}$, although it is worth pointing out that according to EVCA data, Poland is the main market for PE/VC backed IPOs in the region. In the analyzed period it accounted for $90 \%$ of these transactions. The Czech Republic, Slovakia and the Baltic States reported no IPOs between 2004 and 2011 while Romania and Hungary reported two and one IPO respectively.

Another area to be studied is finding reasons for the lower underpricing of PE/VC backed IPOs in comparison with offers carried out by other companies. This would require conducting statistical and econometric analyses of companies' financial data and proxies for information asymmetry, behavioural, institutional and ownership and control factors that may influence the underpricing of $\mathrm{PE} / \mathrm{VC}$ backed offers. The crucial question is whether having a PE/VC fund as a shareholder before an IPO is a factor that has an impact on the occurrence of IPO underpricing and its level.

\section{REFERENCES}

Al-Hassan, A., Delgado, F., Omran, M., IPO Behavior in GCC Countries: Goody-Two Shoes or Bad-to-the-Bone?, International Monetary Fund, WP/07/149, Washington, 2007.

Agarwal, S., Liu, Ch., Rhee S. G., Investor Demand for IPOs and Aftermarket Performance: Evidence from the Hong Kong Stock Market, "Journal of International Financial Markets, Institutions and Money", 18(2), pp. 176-190, 2008.

Aggarwal, R., Rivoli, P., Fads in the Initial Public Offering Market?, "Financial Management", 19(4), pp. 45-57, 1990.

Aggarwal, R., Kunz, R., Why Initial Public Offerings Are Underpriced: Evidence from Switzerland, "Journal of Banking and Finance", Vol. 18, Issue 4, p.705-723, 1994.

Allen, F., Faulhaber, G. R., Signalling by Underpricing in the IPO market, "Journal of Financial Economics", Vol. 23, pp. 303-323, 1989.

Alvarez, S., Gonzalez, V. M., Signalling and the Long-run Performance of Spanish Initial Public Offerings (IPOs), "Journal of Business, Finance and Accounting", Vol. 32 No.1/2, pp. 325-350, 2005.

Anders, A., Why Are So Many New Stock Issues Underpriced?, "Business Review”, Bank of Philadelphia Federal Reserve, March/April 1990.

Aussenegg, W., Privatization Versus Private Sector: Initial Public Offerings in Poland, Multinational Finance Journal, 4 (1-2), pp. 69-99, 2000.

12 The Central and Eastern Europe region includes the following countries: the Czech Republic, Estonia, Hungary, Latvia, Lithuania, Poland, Romania, Slovakia and Slovenia. 
Barber, B., Lyon, J., Detecting Long-Run Abnormal Stock Returns: The Empirical Power and Specification of Test Statistics, "Journal of Financial Economics", 43 (3), pp. 341-372, 1997.

Barry, C., Muscarella, C., Peavy, J., Vetsuypens, M., The Role of Venture Capital in the Creation of Public Companies: Evidence from the Going-public Process, "Journal of Financial Economics" 27(2), pp. 447-471, 1990.

Beatty, R. P., Ritter, J. R., Investment Banking, Reputation and the Underpricing of Initial Public Offerings, "Journal of Financial Economics", Vol. 15, pp. 213-232, 1986.

Bessler, W., Seim, M., European Venture Backed IPOs: An Empirical Analysis, Working Paper, European Venture Capital Association, 2011.

Booth, J. R., Booth, L., Agreeing to Disagree: Why IPOs are Underpriced?, mimeo, July 2003.

Bradley, D., Jordan, B., Ritter, J., Analyst Behavior Following IPOs: The "Bubble Period" Evidence, "Review of Financial Studies" 21(1), pp. 101-133, 2008.

Brav, A., Gompers, P., Myth or Reality? The Long-Run Underperformance of Initial Public Offerings: Evidence from Venture Capital and Non-Venture Capital Backed Companies, "Journal of Finance", 52 (5), pp. 1791-1822, 1997.

Brav, A., Geczy, C., Gompers, P., Is the Abnormal Return Following Equity Issuance Anomalous?, "Journal of Financial Economics", Vol. 56, No. 2, pp. 206-49, 2000.

Chachine, S., The Impact of Founders Ownership, Social Capital and Investors on IPO Stockmarket Performance, "Academy of Management Journal”, August 2006.

Carter, R. B., Dark, F. H., Singh, A. K., Underwriter Reputation, Initial Returns and the Long-run Performance of IPO Stocks, "Journal of Finance", Vol. 53, Issue 1, pp. 285-311, 1998.

Carter, R., Manaster, S., Initial Public Offerings and Underwriter Reputation, "Journal of Finance", Vol. 45, No. 4, pp. 1045-1067, 1990.

Chemmanur, T. J., The Pricing of Initial Public Offerings: A Dynamic Model with Information Production, "Journal of Finance" 48, pp. 285-304, 1993.

Chemmanur, T. J., Fulghieri, P., Reputation, Renegotiation, and the Choice between Bank Loans and Publicly Traded Debt, "Review of Financial Studies", 7-3, pp. 475-506, 1994.

Chemmanur, T. J., Fulghieri, P., A Theory of the Going-public Decision, "Review of Financial Studies" 12, pp. 249-279, 1999.

Chemmanur, T. J., Simonyan, K., Tehraninan, T., Management Quality, Venture Capital Backing, and Initial Public Offering, The Harvard Law School Forum, March 2012.

Chen, C., Mohan, N., Underwriter Spread, Underwriter Reputation and IPO Underpricing: A Simultaneous Equation Analysis, "Journal of Business, Finance and Accounting", Vol. 29 pp. 521-540, 2002.

Chen, G., Firth, M., Krishnan, G. V., Earnings Forecast Errors in IPO Prospectuses and Their Associations with Initial Stock Returns, "Journal of Multinational Financial Management", Vol. 11 No. 4, pp. 225-40, 2001.

Chien-Hsun, C., Shih Hui-Tzu, S., Initial Public Offering and Corporate Governance in China's Transitional Economy, NBER Working Paper No. W9574, March 2003.

Clarkson, P. M., The Underpricing of Initial Public Offerings, Ex Ante Uncertainty and Proxy selection, Accounting and Finance, Vol. 34 No.2, p. 67-78, 1994. 
Coakley, J., Haadas, L., Wood, A., UK IPO Underpricing and Venture Capitalist, "The European Journal of Finance" 15, pp. 421-435, 2009.

Coakley, J., Haadas, L., Wood, A., UK IPO Underpricing and Venture Capitalists, "The European Journal of Finance”, 15(4), 421-435, 2006.

Cochrane, J., The Risk and Return of Venture Capital, "Journal of Financial Economics" 75(1), pp. 3-52, 2005.

Demers, E., Lewellan, K., The Marketing Role of IPOs: Evidence from Internet Stocks, "Journal of Financial Economics", Vol. 68, pp. 413-437, 2003.

Eckbo, B. E., Initial Underpricing of IPOs, mimeo, 2005.

Eckbo, B. E., Norli, O., Liquidity Risk, Leverage and Long-Run IPO Returns, "Journal of Corporate Finance", 11, pp. 1-35, 2005.

Fama, E. F., Agency Problem and the Theory of the Firm, "Journal of Political Economy", Vol. 88 No. 2, pp. 288-308, 1980.

Gompers, P., Grandstanding in the Venture Capital Industry, "Journal of Financial Economics", 42 (1), pp. 133-156, 1996.

Gompers, P., Kovner, A., Lerner, J., Scharfstein, D., Venture Capital Investment Cycles: The Impact of Public Markets, "Journal of Financial Economics", 87(1), pp. 1-23, 2008.

Gompers, P., Lerner, J., Venture Capital Distributions: Short-run and Long-run Reactions, "Journal of Finance", 53(6), pp. 2161-2183, 1998.

Gompers, P., Lerner, J., Money Chasing Deals? The Impact of Fund Inflows on Private Equity Valuations, "Journal of Financial Economics", 55(2), pp. 281-325, 2000.

Gondat-Larralde, C., James, K. R., IPO Pricing and Share Allocation: The Importance of Being Ignorant, "Journal of Finance", Vol. 63, Issue 1, pp. 449-478, 2008.

Gongmeng, C., Firth, M., Kim, J. B., IPO Underpricing in China's New Stock Markets, "Journal of Multinational Financial Management", Vol. 14, No. 2, pp. 283-302, 2004.

Hovey, M., Li, L., Does IPO Underpricing in China Explain a Firm's Long-Term Performance? An Empirical Study of IPOs in China with Corporate Governance Perspectives, http://dx.doi.org/10.2139/ssrn.1009417, January 2009.

How, J., Izan, H., Monroe, G., Differential Information and the Underpricing of Initial Public Offerings: Australian Evidence, "Accounting and Finance", 35 (1), pp. 87-106, 1995.

Hughes, P., Thakor, A., Litigation Risk, Intermediation and Underpricing of Initial Public Offerings, "Review of Financial Studies", Vol. 5, No. 4, pp. 709-742, 1992.

Ibbotson, R., Price Performance of Common Stock New Issues, "Journal of Financial Economics", Vol. 2, No. 3, pp. 235-272, 1975.

Ibbotson, R. G., Jaffe, J. F., Hot Issues Markets, “Journal of Finance”, 30, 1975.

Ibbotson, R., Sindelar, J., Ritter, J., Initial Public Offerings, "Journal of Applied Corporate Finance", Vol. 1, pp. 37-45, 1988.

Jewartowski, T., Lizińska, J., Short-and Long-Term Performance of Polish IPOs, "Emerging Markets Finance and Trade", 48(2), pp. 59-75, 2012.

Knopf, J. D., Teall, J. L., The IPO Effect and Measurement of Risk, "Journal of Financial and Strategic Decisions", Vol. 12, No. 2, pp. 51-58, 1999.

Keloharju, M., The Winner's Curse, Legal Liability and the Long-run Price Performance of Initial Public Offerings in Finland, "Journal of Financial Economics", Vol. 34, Issue 2, pp. 251-277, 1993. 
Konopczak, M., Sieradzki, R., Wiernicki, M., Kryzys na światowych rynkach finansowych wplyw na rynek finansowy $w$ Polsce oraz implikacje dla sektora realnego, "Bank i Kredyt", [Global Financial Markets Crisis - Impact on the Polish Financial Market and Implications for the Real Sector of the Economy]41 (6), National Bank of Poland, Warsaw 2010.

Kothari, S., Warner, J., Measuring Long-Run Horizon Security Price Performance, "Journal of Financial Economics", 43 (3), pp. 301-340, 1997.

Lee, P., Wahl, S. Grandstanding, Certification and the Underpricing of Venture Capital Backed IPOs, "Journal of Financial Economics" 73(2), pp. 375-407, 2004.

Leland, H. E., Pyle, D. H., Informational Asymmetries, Financial Structure, and Financial Intermediation, "Journal of Finance", Vol. 32, Issue 2, pp. 371-387, May 1977.

Lin, T. H., Smith, R. L., Insider Reputation and Selling Decisions: The Unwinding of Venture Capital Investment During Equity IPOs, "Journal of Corporate Finance", Vol. 4, Issue 3, pp. 241-263, 1998.

Liu, X., Ritter, J. R., Local Underwriter Oligopolies and IPO Underpricing, "Journal of Financial Economics", Vol. 102, Issue 3, pp. 579-601, 2011.

Ljungqvist, A., IPO Underpricing, Chapter 7 [in:] Espen Eckbo, B. (ed.) Handbook in Corporate Finance: Empirical Corporate Finance, pp. 375-422. Elsevier, San Diego 2007.

Ljungqvist, A., Wilhelm, W. J., IPO Pricing in the Dot-com Bubble, "Journal of Finance", Vol. 58, Issue 2, pp. 723-752, 2003.

Loughran, T., Ritter, J. R., The New Issues Puzzle, "Journal of Finance”, Vol. 50, No.1, pp. 23-51, 1995.

Loughran, T., Ritter, J. R., Why Don't Issuers Get Upset about Leaving Money on the Table in IPOs?, "Review of Financial Studies", 15(2), pp. 413-444, 2002.

Loughran, T., Ritter, J. R., Why Has IPO Underpricing Increased over Time?, "Financial Management”, 33(3), pp. 5-37, 2004.

Lyn, E. O., Zychowicz, E. J., The Performance of New Equity Offerings in Hungary and Poland, "Global Finance Journal”, Vol. 14, Issue 2, pp.181-95, 2003.

Lyon, J., Barber, B., Tsai, C., Improved Methods for Tests of Long-Run Abnormal Stock Returns, "Journal of Finance", 54 (1), pp. 165-201, 1999.

Megginson, W., Weiss, K., Venture Capitalist Certification in Initial Public Offerings, "Journal of Finance", Vol. 46, Issue 3, pp. 879-903, 1991.

Menyah, K., Paudyal, K., Inyangete, C., Subscriber Return, Underpricing, and Long-term Performance of UK Privatization Initial Public Offers, "Journal of Economics and Business", Vol. 47, No. 5, pp. 473-495, 1995.

Michaely, R., Shaw, W., The Pricing of Initial Public Offerings: Tests of Adverse-selection and Signalling Theories, "Review of Financial Studies", Vol. 7, No. 2, pp. 279-319, 1994.

Mok, M. K., Hui, Y. V., Underpricing and Aftermarket Performance of IPOs in Shanghai, China, "Pacific-Basin Finance Journal", Vol. 6, Issue 5, pp. 453-474, 1998.

Neus, W., Waltz, U., Exit Timing of Venture Capitalists in the Course of an Initial Public Offering, "Journal of Financial Intermediation", Vol. 14, Issue 2, pp. 253-277, 2005. 
Parkinson, M., The Extreme Value Method for estimating The Variance of the Rate of Return, "Journal of Business", Vol. 53, No. 1, pp. 61-65, 1980.

Paudyal, K., Saadouni, B., Briston, R. J., Privatization Initial Public Offerings in Malaysia: Initial Premium and Long-Term Performance, "Pacific-Basin Finance Journal", Vol. 6, Issue 5, pp. 427-451, 1998.

Pritsker, M., A Fully-Rational Liquidity-Based Theory of IPO Underpricing. Federal Reserve Board, Washington D.C., 2006.

Rhee, S. G., A Review of the New Issue Puzzles, OECD Round Table on Capital Markets, Round Table on Capital Market Reform in Asia, Tokyo, Japan 9-10 April, 2002.

Ritter, J. R., The "Hot Issue” Market of 1980, “Journal of Business”, Vol. 57, No. 2, pp. 215240, 1984.

Ritter, J. R., The Long-Run Performance of Initial Public Offerings, "Journal of Finance", Vol. 46, Issue 1, pp. 3-27, 1991.

Ritter, J. R., Differences between European and American IPO Markets, "European Financial Management", Vol. 9, No. 4, pp. 421-434, 2003.

Ritter, J. R., Money Left on the Table in IPOs by Firm, University of Florida, Working Papers, January 2006.

Ritter, J. R., Welch, I., A Review of IPO Activity, Pricing, and Allocations, "Journal of Finance", Vol. 57, Issue 4, pp. 1795-1828, 2002.

Rock, K., Why New Issues Are Underpriced, "Journal of Financial Economics”, Vol. 15, Issues 1-2, pp. 187-212, 1986.

Sahlman, W., The Structure and Governance of Venture-capital Organizations, "Journal of Financial Economics", Vol. 27, Issue 2, pp. 473-521, 1990.

Sanders, A., Why Are So Many New Stocks Issues Underpriced?, Federal Reserve Bank of Philadelphia, "Business Review”, pp. 3-12, March/April 1990.

Shefrin, H., Statman, M., The Disposition to Sell Winners Too Early and Ride Losers Too Long: Theory and Evidence, Journal of Finance Vol. 40, Issue 3, pp. 777-790, 1985.

Sieradzki, R., Does It Pay To Invest In IPOs? Evidence from the Warsaw Stock Exchange, NBP Working Paper No. 139(2013), National Bank of Poland, Warsaw 2013.

Sukacz, D., Pierwsze oferty publiczne na rynkach kapitałowych, [Initial Public Offerings on the Capital Markets]. CeDeWu, Warszawa 2005.

Ting, Y. U., Tse, Y. K., An Empirical Examination of IPO Underpricing in the Chinese A-share Market, "China Economic Review", Vol. 17, Issue 4, pp. 363-382, 2006.

Zasępa, P., Venture Capital, Sposoby dezinwestycji [Venture Capital, Divestment Methods]. Cedewu, Warszawa 2010.

Received: January 2014, revised: August 2015 


\section{APPENDIX}

List of PE/VC backed IPOs on the Warsaw Stock Exchange, 2003-2011

\begin{tabular}{|c|c|c|c|c|}
\hline & Year & Company & $\begin{array}{l}\text { Initial return } \\
\text { in } \%\end{array}$ & $\begin{array}{c}\text { Offer value } \\
\text { in PLN million }\end{array}$ \\
\hline 1 & 2004 & Techmex & -2.33 & 120.00 \\
\hline 2 & & Intercars & 7.14 & 80.24 \\
\hline 3 & & Comp Rzeszów & 29.79 & 187.53 \\
\hline 4 & & ATM & -8.18 & 46.80 \\
\hline 5 & & Praterm & 3.50 & 110.00 \\
\hline 6 & 2005 & Zelmer & 32.58 & 169.04 \\
\hline 7 & & Zetkama & -8.93 & 11.90 \\
\hline 8 & & PEP & -7.69 & 35.81 \\
\hline 9 & & Opoczno & 0.00 & 455.97 \\
\hline 10 & & Travelplanet & 11.11 & 6.67 \\
\hline 11 & & Jago & 17.50 & 19.92 \\
\hline 12 & & Teta & 30.39 & 31.42 \\
\hline 13 & 2006 & Sfinks & 0.36 & 91.83 \\
\hline 14 & & Ergis & 0.00 & 32.21 \\
\hline 15 & & Bankier.pl & 5.33 & 25.13 \\
\hline 16 & & Mispol & 11.25 & 42.80 \\
\hline 17 & & eCard & 85.00 & 14.00 \\
\hline 18 & & Qumak Sekom & 1.83 & 63.77 \\
\hline 19 & & One2One & 55.00 & 13.00 \\
\hline 20 & & $\mathrm{AB}$ & 1.74 & 74.09 \\
\hline 21 & & Fota & 0.59 & 99.14 \\
\hline 22 & 2007 & Hawe & 34.72 & 36.00 \\
\hline 23 & & Gadu-Gadu & 16.19 & 104.13 \\
\hline 24 & & ACE & 0.00 & 256.01 \\
\hline 25 & & Mercor & 36.59 & 243.14 \\
\hline 26 & & Magellan & 4.76 & 54.60 \\
\hline 27 & & $\mathrm{CP}$ energia & 9.44 & 29.70 \\
\hline 28 & & Bipromet & -4.08 & 22.27 \\
\hline 29 & 2008 & $\mathrm{~K} 2$ & -6.00 & 18.75 \\
\hline 30 & 2010 & ABC Data & 0.43 & 79.41 \\
\hline 31 & & Harper Hygienics & 14.63 & 53.30 \\
\hline 32 & 2011 & Kruk & 5.06 & 369.21 \\
\hline 33 & & Enel-Med & 1.80 & 35.50 \\
\hline
\end{tabular}

Source: own calculations 